\title{
Human-wildlife conflicts with crocodilians, cetaceans and otters in the tropics and subtropics
}

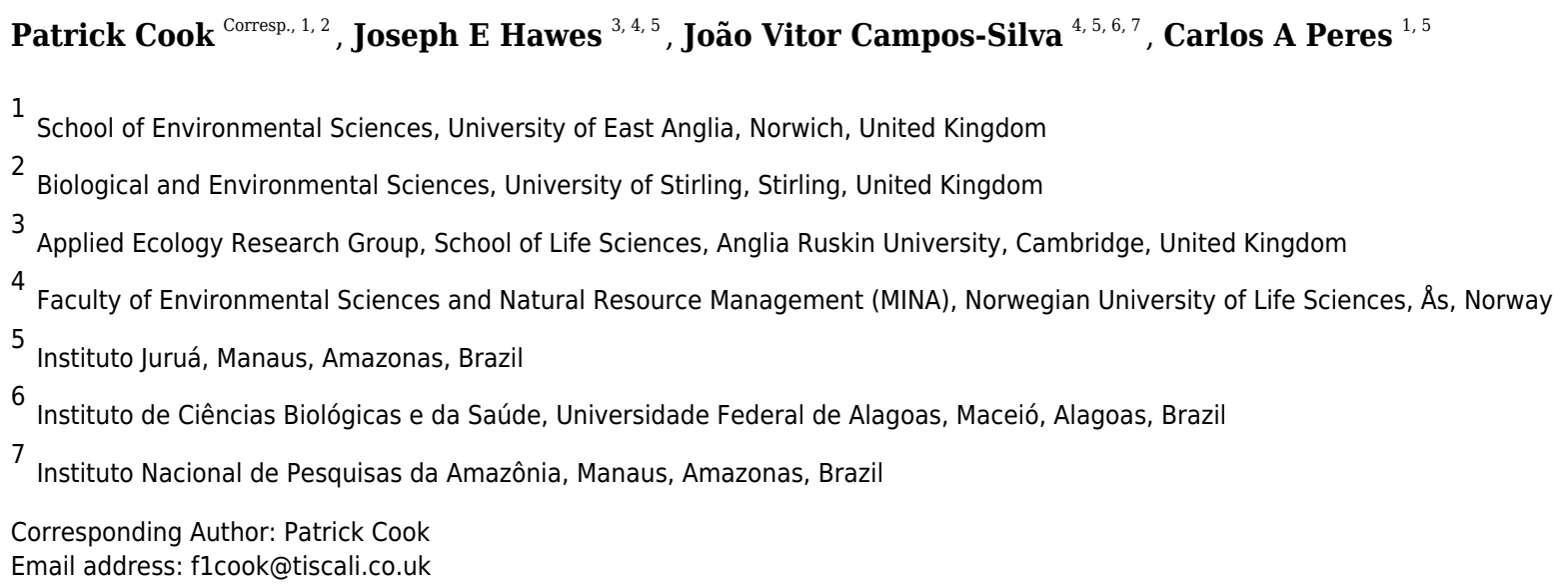

Conservation of freshwater biodiversity and management of human-wildlife conflicts are major conservation challenges globally. Human-wildlife conflict occurs due to attacks on people, depredation of fisheries, damage to fishing equipment and entanglement in nets. Here we review the current literature on conflicts with tropical and subtropical crocodilians, cetaceans and otters in freshwater and brackish habitats. We also present a new multispecies case study of conflicts with four freshwater predators in the Western Amazon: black caiman (Melanosuchus niger), giant otter (Pteronura brasiliensis), boto (Inia geoffrensis) and tucuxi (Sotalia fluviatilis). Documented conflicts occur with 34 crocodilian, cetacean and otter species. Of the species reviewed in this study, 37.5\% had conflicts frequently documented in the literature, with the saltwater crocodile (Crocodylus porosus) the most studied species. We found conflict severity had a positive relationship with species body mass, and a negative relationship with IUCN Red List status. In the Amazonian case study, we found that the black caiman was ranked as the greatest 'problem' followed by the boto, giant otter and tucuxi. There was a significant difference between the responses of local fishers when each of the four species were found entangled in nets. We make recommendations for future research, based on the findings of the review and Amazon case study, including the need to standardise data collection. 


\section{Human-Wildlife Conflicts with Crocodilians, Cetaceans and}

\section{Otters in the Tropics and Subtropics}

3

4 Patrick Cook ${ }^{1,2}$, Joseph E. Hawes ${ }^{3,4,5}$, João Vitor Campos-Silva ${ }^{4,5,6,7}$, Carlos A. Peres ${ }^{1,5}$

5

$6{ }^{1}$ School of Environmental Sciences, University of East Anglia, Norwich Research Park, Norwich, UK

$7 \quad{ }^{2}$ Current Address: Biological and Environmental Sciences, University of Stirling, Stirling, UK

$8{ }^{3}$ Applied Ecology Research Group, School of Life Sciences, Anglia Ruskin University, East Road,

9 Cambridge, UK

$10{ }^{4}$ Faculty of Environmental Sciences and Natural Resource Management, Norwegian University of Life

11 Sciences, Ås, Norway

$12{ }^{5}$ Instituto Juruá, Rua Belo Horizonte 19, Manaus, Brazil

$13{ }^{6}$ Instituto Nacional de Pesquisas da Amazonia, Manaus, Amazonas, Brazil

$14{ }^{7}$ Instituto de Ciências Biológicas e da Saúde, Universidade Federal de Alagoas, Maceió, Alagoas, Brazil

17 Corresponding Author:

18 Patrick Cook ${ }^{1,2}$

19 Biological and Environmental Sciences, University of Stirling, Stirling FK9 4LA, UK

20 Email address: patrick.cook@stir.ac.uk 


\section{Abstract}

22 Conservation of freshwater biodiversity and management of human-wildlife conflicts are major 23 conservation challenges globally. Human-wildlife conflict occurs due to attacks on people,

24 depredation of fisheries, damage to fishing equipment and entanglement in nets. Here we review 25 the current literature on conflicts with tropical and subtropical crocodilians, cetaceans and otters 26 in freshwater and brackish habitats. We also present a new multispecies case study of conflicts 27 with four freshwater predators in the Western Amazon: black caiman (Melanosuchus niger), 28 giant otter (Pteronura brasiliensis), boto (Inia geoffrensis) and tucuxi (Sotalia fluviatilis). 29 Documented conflicts occur with 34 crocodilian, cetacean and otter species. Of the species 30 reviewed in this study, $37.5 \%$ had conflicts frequently documented in the literature, with the 31 saltwater crocodile (Crocodylus porosus) the most studied species. We found conflict severity 32 had a positive relationship with species body mass, and a negative relationship with IUCN Red 33 List status. In the Amazonian case study, we found that the black caiman was ranked as the 34 greatest 'problem' followed by the boto, giant otter and tucuxi. There was a significant 35 difference between the responses of local fishers when each of the four species were found 36 entangled in nets. We make recommendations for future research, based on the findings of the 37 review and Amazon case study, including the need to standardise data collection. 


\section{Introduction}

Conflict between humans and wildlife poses a major challenge for biological conservation (Dickman, 2010). Human-wildlife conflicts arise as a result of recurring negative interactions between humans and wildlife and are frequently deep rooted in social beliefs (Pimm \& Raven, 2000). Understanding the underlying factors driving conflicts is integral to successful management, due to the often-increasing proximity between humans and wildlife, driven by growing human populations and the recovery of rare, conflict-generating species (Inskip \& Zimmermann, 2009; Groenendijk et al., 2014). Increasing our knowledge of conflicts in freshwater and brackish ecosystems, between humans and piscivores, is especially important in the tropics and subtropics, given the heavy exploitation pressure and continued decline of wildlife populations (He et al., 2019).

Freshwater habitats cover approximately 3\% of the Earth's land surface area (Pekel, 2016), exposing vertebrates to potential conflicts with disproportionately high densities of humans, as a result of overlapping distributions and utilisation of similar resources (Woodroffe \& Ginsberg, 1998; Treves \& Karanth, 2003; Dudgeon et al., 2006). Piscivores can impose significant impacts on human livelihoods in freshwater and brackish environments, including attacks on people and damage to fishing gear, in addition to co-depletion of fish stocks (RosasRibeiro, Rosas \& Zuanon, 2012; Sideleau \& Britton, 2013). Managing such conflicts to ensure long-term persistence of wildlife populations is vital to maintaining ecosystem integrity (Rio et al., 2001). Yet this is particularly challenging in tropical and subtropical regions where freshwater fisheries more often represent a critical component of the subsistence diets and commercial revenues of local people (Michalski et al., 2012).

Potential conflicts within marine fisheries have been well documented and show negative impacts on both the conservation of large marine predators and the socio-economic viability of fishing activities (Tixier et al., 2021). However, despite the importance of inland fisheries, a review of the conflicts reported in freshwater and inland brackish systems such as estuaries and lagoons has not yet been undertaken. Here, we address this research gap by investigating conflicts between humans and three major groups of piscivores (crocodilians, cetaceans and otters) found throughout the tropics and subtropics, through (i) a case study from western Brazilian Amazonia, and (ii) a global literature review. 
68

69

70

71

72

73

74

75

76

77

78

79

80

81

82

83

84

85

86

87

88

89

90

91

92

93

94

95

96

97

98

Crocodilians, cetaceans and otters are responsible for high levels of conflict in the Amazon (Loch, Marmontel \& Simões-Lopes, 2009; Fonseca \& Marmontel, 2011; Alves, Zappes \& Andriolo., 2012; Lima et al., 2014a), one of the most important freshwater habitats on Earth where the majority of rural people depend on fisheries (Begossi et al., 2018). Yet most humanwildlife conflicts in the vast Amazonian basin are likely to be unreported; our case study surveys a remote region with no previous documentation of human-wildlife conflicts. We specifically tested: (1) which species are most involved in human-wildlife conflicts; and (2) what types of conflicts occur for each species. Distance to the nearest urban area or access to aquatic habitats (such as seasonally flooded forests) could influence conflict severity by altering the probability of interactions occurring between humans and wildlife (Rosas-Ribeiro, Rosas \& Zuanon, 2012). We therefore also tested (3) whether proximity to the nearest town predicts human-wildlife conflict severity; and (4) whether percentage of seasonally flooded forest around communities predicts human-wildlife conflict severity.

To provide a global context for this case study, we conducted a quantitative literature review, which we restricted to the same three taxonomic groups for consistency. Specific research questions for the literature review include: (1) how many and which species of crocodilians, cetaceans and otters are involved in human-wildlife conflicts?; (2) what types of human-wildlife conflicts occur?; (3) what is the frequency of conflict documented in the primary literature for each species?; and (4) what is the conflict severity for each species?

Species involved in conflicts are often large-bodied and slow to reproduce, and their population status can be directly or indirectly affected by the conflict (Alves, Zappes \& Andriolo., 2012; Huang et al., 2012; Groenendijk et al., 2014). Conflict severity may be expected to be positively related to body mass, due to the greater threat posed to human life by larger-bodied animals, as well as increased potential damage to fishing equipment and greater risk of the species being exploited. It may also be expected that conflict severity would be higher for less threatened species (as indicated by IUCN Red List status), due to more frequent human interactions with more common species. As additional research questions, we therefore tested: (5) how well body mass predicts human-wildlife conflict severity; and (6) how well IUCN threat status predicts human-wildlife conflict severity.

Materials \& Methods 


\section{Focal study area}

Our focal landscape study was conducted in the state of Amazonas, Brazil along the midsection of the Juruá River in two contiguous sustainable-use forest reserves: the Médio Juruá Extractive reserve (ResEx Médio Juruá), and the Uacari Sustainable Development Reserve (RDS Uacari) (Fig. 1). These two reserves are home to a combined total of approximately 4,000 rural Amazonians, living in 58 communities and employed in a diverse range of extractive livelihoods (Newton, Endo \& Peres, 2012). Communities typically have access to extensive floodplains and are located along the main river channel or on oxbow lakes, which are embedded within forests that are seasonally flooded by nutrient-rich white-water, known as várzea (Hawes et al., 2012). Communities are therefore deeply entwined with their aquatic environment, and fishing represents both the principal source of protein in the subsistence diet of reserve residents (Endo, Peres \& Haugaason, 2016), and one of the main sources of disposable income (Batista et al., 1998). Our focal study reserves represent an important site for globally significant communitybased conservation arrangements (Campos-Silva \& Peres, 2016; Campos-Silva et al., 2018) that benefit a wide range of large-bodied freshwater piscivores, including the black caiman (Melanosuchus niger), the giant otter (Pteronura brasiliensis), and two cetaceans: the Amazon river dolphin or boto (Inia geoffrensis) and the tucuxi (Sotalia fluviatilis) (Fig. 2).

\section{Fisher interviews}

We employed a semi-structured questionnaire design to investigate perceptions of human-wildlife conflict involving four species of aquatic fauna: black caiman, giant otter, boto and tucuxi. Two interviewers (JEH \& JVCS) conducted a total of 49 interviews at 37 local communities located within the two sustainable-use reserves in the Médio Juruá region (Fig. 1), during September-November 2014. We selected interviewees non-randomly, targeting the most experienced fishers in each community (either one individual or a small group of individuals). Interviews typically lasted 30 minutes and interviewees rank-ordered the potential problem of the conflict caused, with 1 being the greatest problem and 4 the least (Michalski et al., 2012). In addition, we included eight objective yes/no questions asking whether any of the focal species cause problems, damage equipment, become entangled in nets, frighten away fish, or cause the interviewee to leave an area to fish elsewhere when the species has been sighted, and whether co-existence with the focal species in the future depends on continued increases in its population. 
130 Interviewees were asked what their most likely response would be to finding one of the four 131 species entangled in their fishing nets, such as killing or releasing the individual, if the species 132 could escape of its own accord or if it was likely to die before being found. Interviewees were 133 also asked if the species had been hunted in the community, hunted within the last two years 134 (2013 or 2014), or hunted within the informant's lifetime.

135 We thank the Secretaria do Estado do Meio Ambiente e Desenvolvimento Sustentável 136 (SDS-DEMUC) and the Instituto Chico Mendes de Conservação da Biodiversidade (ICMBio) 137 for authorising this research.

138

139

\section{Literature review}

To provide a global context for our local case study, we conducted a literature review of human-wildlife conflicts, for all species of tropical and subtropical freshwater crocodilians, cetaceans and otters. Piscivores other than crocodilians, cetaceans and otters were not included in the study to ease comparison between the local case study and the wider literature review. Studies conducted outside the tropics and subtropics (35 degrees north and south of the equator) were excluded to ensure that data gathered from the literature review and case study were within the same latitudinal range. We focused on freshwater and brackish habitats, excluding any studies only from marine habitats. Similarly, studies that focused on interactions with fisheries were restricted to wild fisheries and excluded human-made fisheries such as aquaculture. We also excluded reports of attacks by animals in captivity, and attacks by wild animals on either livestock or pets.

Primary literature sources were collated from Google Scholar and Scopus. Two researchers (PC \& JEH) conducted a general search using the keywords: conflicts, crocodilians, cetaceans and otters, before using a Boolean search string search that included the common or scientific name of a species, together with the following keywords: attack, conflict, depredation, entanglement, perceptions and damage. The string search was conducted in the following format (( "common name" OR "synonym" OR "scientific name" ) AND ( attack* OR conflict OR depred* OR entangle* OR perce* OR damage )). Additional articles were located through searching reference lists (snowballing) and subsequent citations (reverse snowballing). All keyword searches were conducted in English, which may have excluded some studies. For each 
160 literature source we documented the country of study and categorised the broad types of conflict 161 documented such as attacks, net damage, depredation, entanglement and perceptions.

162 For each species, we categorised the frequency of documented conflict based on the 163 number of primary literature sources referring to conflict with the species, 5 or more being 164 frequently documented, 2-4 being infrequently documented and 1 being rarely documented 165 (Table 1). We described the severity of conflict for each species, based on criteria adapted from 166 Inskip and Zimmermann (2009) (Table 1). Body mass in kilograms was also attributed using the 167 following categories $\leq 10 \mathrm{~kg}, 11-49 \mathrm{~kg}, \geq 50 \mathrm{~kg}$ adopted from Inskip \& Zimmermann (2009) 168 (Macdonald, 2009; Hunter, 2011; Lakin et al., 2020). We also assigned Red List Status using the 169 IUCN Red List (IUCN, 2020). Category scores were assigned by PC and independently scored 170 by JEH to check for inter-observer consistency.

171

172

Data analysis

173 In the case study, we used a chi-squared test to determine if the species differed in their 174 ranking as a 'problem species'. A Mann-Whitney U test was used to investigate the level of 175 conflict among the study species, and a chi-squared test was used to determine if the response of 176 fishers to entanglement in fishing nets differed among species. We also calculated the nonlinear 177 fluvial distance from the nearest urban centre, Carauari, to each community and the percentage 178 of várzea floodplain forest within $5 \mathrm{~km}$ of each community, using ArcGIS v 10.2.2 (ESRI, 179 2014). We then examined the influence of fluvial distance to Carauari and percentage várzea 180 forest cover on the eight binary interview questions using binary logistic regression. For the 181 literature review, we used Spearman's rank correlation to investigate the change in the number of 182 reviewed studies over time. A Fisher's Exact Test was implemented to determine if the severity 183 of conflict differs between animal body mass categories $(<10 \mathrm{~kg}, 10-49 \mathrm{~kg}, \geq 50 \mathrm{~kg})$ or the 184 species IUCN Red List category. All data analysis was conducted by PC \& JEH, using SPSS v 18522 (IBM Corporation, 2014) and R v 1.4.1106 (R Core Team, 2020).

187 Results

188 Amazonian case study

189 Interview responses showed a significant difference between the perception of black

190 caiman, giant otters, botos and tucuxis as problem species (Chi-squared: $\chi^{2}=204.69$, d.f. $=3$, p $<$ 
$1910.001, \mathrm{n}=49$ ). Black caiman was consistently regarded as the greatest source of conflicts (mean 192 rank = 1.37), followed by the boto (2.06), giant otter (2.52) and tucuxi (4.00) $(\mathrm{n}=49)$. The black 193 caiman was ranked significantly higher as a 'problem species' than the boto (Mann-Whitney: U $194=573.5, \mathrm{Z}=-4.841, \mathrm{p}<0.001, \mathrm{n}=49$ ), and the boto was ranked significantly higher than the 195 giant otter $(U=714.0, Z=-3.195, p<0.001, n=49)$. Of the 49 interviews conducted, $100 \%$ of 196 interviewees reported black caiman and boto as 'problem species', followed by $89.8 \%$ for the 197 giant otter (Fig. 3). In the study area, at least nine cases of lethal attacks on humans by black

198 199

200

201

202

203

204 205

206

207

208

209

210

211

212

213

214

215

216

217

218

219

220

221 caiman involving both adults and children have been reported between 2007 and 2020, a rate of about 0.3 persons killed each decade per 1,000 people (C. Peres, pers. comm.).

Fishers' responses showed a significant difference among all species regarding the outcomes whenever found entangled in fishing nets $\left(\chi^{2}=152.12\right.$, d.f $\left.=9, \mathrm{p}<0.001, \mathrm{n}=49\right)$. Black caimans were reported to be killed by $93.0 \%$ of fishers (Fig. 4). In contrast, $79.0 \%$ of botos and $85.7 \%$ of tucuxi were released alive, and $40.0 \%$ of interviewees stated that giant otters could escape from gillnets without assistance (Fig. 4). In response to conflicts with the black caiman, $16.7 \%$ of interviewees reported that they changed fishing locations as a result, compared to $33.3 \%$ for the giant otter, $12.5 \%$ for the boto and no interviewees for the tucuxi. Giant otters were reported by $50.0 \%$ of interviewees as being responsible for a perceived decline in matrinxã, and $97.9 \%$ of interviewees stated that giant otters spatially displace fish (Fig. 3). Most interviewees reported that they could continue coexisting with these four species if populations were to increase in the future, ranging from $60.4 \%$ of interviewees who considered that coexistence with the black caiman is possible, to $75.0 \%$ for the tucuxi (Fig. S1). With the exception of one variable, no interviewee responses showed a significant relationship with fluvial distance from the nearest urban centre of Carauari or the percentage of várzea floodplain forest found within a 5-km buffer area around each community (Table S1). The exception is the damage caused to gillnets by giant otters, which increased with fluvial distance from Carauari (binary logistic regression: $\beta=0.007, \mathrm{p}=0.009, \mathrm{n}=49$ ).

\section{Literature review}

A total of 143 studies were published between 1962 and 2020, and the number of sources published per year increased over time, including years with no studies reported (Spearman's: $r_{s}$ $=0.882, \mathrm{p}<0.001, \mathrm{n}=59$; Fig. 5). These studies covered 33 countries in the tropics and 
222 subtropics across Africa, Asia, Australia, North America and South America. Brazil was the 223 country with the most studies undertaken $(n=24)$, followed by India $(n=20)$ and Australia $(n=$ 224 19). All other countries had seven or fewer studies. The compiled studies reported conflicts with 22534 species of crocodilians, cetaceans and otters (Table 2). Types of conflicts reported with these 226 species included attacks on humans, depredation of fish, damage to fish nets, competition for 227 economically important fish species and entanglement in fishing equipment.

Attacks on humans accounted for $30.8 \%$ of studies (Table 2). The literature included 44

229

230

231

232

233

234

235

236

237

238

239

240

241

242

243

244

245

246

247

248

249

250

251

252

studies concerning sub-lethal or lethal attacks by crocodilians, one study for otters and none for cetaceans. Economic and livelihood impacts such as net damage or competition for fish accounted for $28.7 \%$ of studies (Table 2). Otters accounted for $50.0 \%$ of the species documented in the literature under this category, with the giant otter the most cited species accounting for $18.4 \%$ of these studies. The Nile crocodile (Crocodylus niloticus) (8.2\% of studies) and boto $(8.2 \%)$ were the most cited crocodilian and cetacean respectively. Studies focused on entanglement in fishing nets comprised $19.6 \%$ of the literature (Table 2). These studies covered five species of crocodilian and six species of cetaceans, the latter accounting for $87.1 \%$ of all studies on entanglement. Management or resolution of conflict was the subject of only $10.5 \%$ of all studies covering five countries, notably Australia which accounted for $60.0 \%$ of management studies (Table 2). Perceptions of conflict accounted for $9.8 \%$ of studies, across 15 crocodilians, eight otters and seven cetaceans (Table 2).

The frequency of reported conflicts varied across species; $35.7 \%$ of species were frequently documented, $21.4 \%$ infrequently documented, $14.3 \%$ rarely documented and 28.6\% listed as data deficient with no evidence or documentation of conflict occurring (Table 2). Over half $(50.3 \%)$ of all studies included reports of conflicts with crocodilians, while approximately a quarter of studies reported conflicts for cetaceans (26.6\%) or otters (23.1\%) (Table 2). Five species accounted for nearly half (49.7\%) of all studies: the saltwater crocodile (Crocodylus porosus) (33 studies), Amazon river dolphin (14), Nile crocodile (14), South Asian river dolphin (Platanista gangetica) (14) and the giant otter (11). Six species listed as either endangered or critically endangered on the IUCN Red List had no documentation of conflict occurring.

Only crocodilians were assigned to the severe and high conflict categories, with four and five species in each respectively. The North American river otter (Lontra canadensis) was the only non-crocodilian species to be assigned a conflict severity category of moderate. All other 
253 otters and cetaceans were classified as low conflict severity. The severity of conflict differed

254 significantly among body mass categories, with larger species more likely to be involved in 255 severe conflicts (Fisher's Exact Test: $\mathrm{p}<0.05$; Table 3). The severity of conflict also differed 256 significantly among IUCN Red List categories, with species classified in less threatened 257 categories displaying higher levels of conflict (Fisher's Exact Test: $\mathrm{p}<0.01$; Table 3). 258

\section{Discussion}

260

261

262

263

264

265

266

267

268

269

270

271

272

273

274

275

276

277

278

279

280

281

282

283

\section{Amazonian Case Study}

We found that interviewee responses displayed significant differences between the perceptions of black caiman, giant otter, boto and tucuxi as 'problem species'. The consistent identification of black caiman as the highest-ranking problem species reflects the level of direct threat to human life that the black caiman poses, and most adults in the middle-third of the Juruá River basin know, or have heard of someone, who has been killed by a black caiman within their lifetimes. This finding was in strong agreement with our literature review where all the case study species except the black caiman were classified as low severity. That the differences in conflict severity between the giant otter, boto and tucuxi reported in our case study were not also detected in the literature review reflects our focus on attacks in the latter. Despite these existing conflicts, most interviewees reported that they could continue living in proximity with these four species, even if their populations were to increase in the future. The percentage of interviewees agreeing with this statement reflected the problem ranking status, being lowest for the black caiman.

Fishers' typical responses to entanglement in fishing nets of the four study species differed, with black caiman typically killed, botos and tucuxis released, and the giant otter often dying before being discovered. This can partly be explained by the differing ability of each species to escape entanglement in nets, with $40.0 \%$ of interviewees stating that giant otters could escape (Fig. 4). This value is much higher than for the black caiman, boto or tucuxi, reflecting the ability of giant otters to tear through nets with their teeth and dexterous paws. For the boto, our findings differ from reports in other areas, such as the Central Amazon where this species is intentionally killed as bait for piracatinga catfish (Calophysus macropterus) fisheries (Loch, Marmontel \& Simões-Lopes, 2009; Alves, Zappes \& Andriolo., 2012). The positive relationship that we found between damage to gill-nets by the giant otter and distance from the nearest town, 
284 is challenging to explain. It is likely that giant otter abundance increases at greater distances from 285 urban centres, particularly given historic range wide declines due to hunting pressure (Antunes et 286 al., 2016), which could result in more frequent depredation of fish further from towns. However, 287 without reliable survey data for the giant otter population in the study area it is not currently 288 possible to confirm this.

289 We found no relationship between interviewee responses and percentage of várzea 290 floodplain forest found within a 5-km buffer area around each community. This was in contrast 291 to our expectation that greater access to aquatic habitat would raise conflict severity by 292 increasing the proximity and potential for interactions between humans and the study species.

293 One possible explanation for the absence of a clear relationship here could be the additional role 294 of seasonal variation. For example, conflict occurrence may be higher in the wet season, when 295 water levels rise allowing aquatic species access to the flooded forest (Junk et al., 2011). There is 296 some evidence that conflict with giant otters is highest during the wet season, when fish disperse 297 into the flooded forest and otters become more generalist, targeting vulnerable species (Cabral et 298 al., 2010; Rosas-Ribeiro, Rosas \& Zuanon, 2012). This happens to coincide with the time of year 299 when the income for fishers tends to be lowest (Junk, 1984; Cabral et al., 2010; Rosas-Ribeiro, 300 Rosas \& Zuanon, 2012), which could exacerbate any potential conflicts.

301

302

303

304 305 306 307 308 309 310 311 312 313 documented than for freshwater fisheries, although rigorous evaluation of these proposals 314 remains poor (Inskip \& Zimmermann, 2009). However, depredation of fish stocks and net

\section{Fish Depredation and Net Damage}

The growing spatial overlap between humans, crocodilians, cetaceans and otters has in some locations increased negative interactions. This may result in attacks on people, economic losses or coincidental declines in fish stocks, with these species potentially blamed or persecuted even if overfishing is the driving factor (Gopi \& Pandav, 2009; Recharte, Bowler \& Bodmer, 2009; Fukuda, Manolis \& Appel, 2014; Lima, Marmontel \& Bernard, 2014a).

Economic losses from fish depredation and net damage are often cited in the literature but studies that provide quantifiable, standardised data and solutions to resolve them are limited (Aust et al., 2009). Levels of depredation are currently far better compiled for marine ecosystems, together with proposed methods to reduce depredation (Tixier et al., 2021). Methods

312 for reducing predation in terrestrial ecosystems, e.g. of felids on pastoral livestock, are also better 
315 damage by aquatic animals can still be extensive (Aust et al., 2009; Barbieri et al., 2012). Our

316 literature review confirmed that crocodilians, cetaceans and otters from across the tropics and

317 subtropics are all reported to depredate fish, damaging nets in the process and cause competition

318 with commercial and subsistence fisheries by catching commercially valuable fish and displacing 319 fish.

320 Riverine communities in tropical and subtropical regions worldwide often depend on fish

321 for both dietary protein and financial income, and damage to nets can therefore severely impact

322 their livelihoods (Michalski et al., 2012). Our case study found the black caiman, giant otter and

323 boto all damage fishing equipment in Amazonia and, although we did not document the

324 frequency or economic severity of this damage in the Juruá, black caiman have been reported to

325 damage up to $50.0 \%$ of commercially deployed gill nets elsewhere in the Amazon (Peres \&

326 Carkeek, 1993). Replacement of fishing nets is likely to have major financial ramifications for

327 fishers with limited resources, as in Namibia where approximately 71,500 nets are damaged

328 annually by the Nile crocodile and the purchase of new nets can often exceed monthly income

329 (Aust et al., 2009).

330 Compared to crocodilians, depredation by otters, mostly involves the giant otter,

331 particularly in relation to matrinxã (Brycon cephalus) fisheries in the western Amazon, which are

332 important for both subsistence and trade (Santos, Ferreira \& Zuanon., 2006; Rosas-Ribeiro,

333 Rosas, \& Zuanon, 2012). Perceived competition can lead to retaliatory killing of 'problem

334 individuals' which has detrimental impacts on the species by reducing population recovery

335 (Brum et al., 2021), and resource depletion of fisheries can further intensify competition and

336 conflict. Economic losses due to cetaceans are documented in both South America and Asia

337 (Kelkar et al., 2010; Alves, Zappes \& Andriolo., 2012; Campbell et al; 2020). There are

338 consistent reports of the boto raiding and damaging nets, with all interviewees in our case study

339 supporting findings from elsewhere in the Amazon (Alves, Zappes \& Andriolo., 2012; Campbell

340 et al; 2020). This contrasts sharply with the sympatric tucuxi, reflecting the greater levels of

341 animosity towards the boto and potential differences in foraging strategy between these two

342 species (Martin \& da Silva, 2004; Alves et al., 2012).

343

344 Entanglement 

but also threatens crocodilians and otters, with impacts ranging from injury to death across all 347 groups (Platt \& Thorbjarnarson, 2000; Choudhary et al., 2006; Alves, Zappes \& Andriolo., 348 2012). All four species in our Amazonian case study were reported by local fishers to become 349 entangled in nets. Specific net types, such as seine nets or nets with polyamide threads, may 350 increase the risk of fatality from entanglement for both otters and cetaceans (Leatherwood \& Reeves, 1994; da Silva \& Best, 1996; Lima, Marmontel \& Bernard, 2014b).

Bycatch through entanglement may be as important for population trends in aquatic animals as for those in the marine realm (Mangel et al., 2013; Anderson et al., 2020; Tixier et al., 2021). For example, entanglement is cited as the primary source of conflict and a contributor to population declines for both the boto and tucuxi (Campbell et al; 2020), with the latter now listed as endangered on the IUCN Red List (da Silva et al., 2018; IUCN, 2020; Brum et al., 2021). This has resulted in all river dolphin species worldwide now being listed as endangered, critically endangered or extinct (IUCN, 2020). In extreme circumstances entanglement can even contribute to extinction (Jaramillo-Legorreta et al., 2019), such as the case of the Yangtze river dolphin (Lipotes vexillifer) where 40\% of fatalities during the 1990s were attributed to this factor (Zhou et al., 1998; Zhang et al., 2003; Turvey et al., 2007). Techniques to prevent entanglement, such as acoustic deterrent pingers, have been developed for use in marine ecosystems and their effectiveness for freshwater cetaceans has now begun to be tested (Waples et al., 2013; Prajith, Das \& Edwin, 2014; Snape et al., 2018; Tixier et al., 2021; Zanon, 2021). are often influenced by local perceptions and economics (Sinha, 2002; Alves, Zappes \& Andriolo., 2012; Campbell et al., 2020). In our case study, we found that the response between the four studies species varied greatly, with black caiman often killed and exploited as a food source. The probability of being killed rather than released likely reflects the level of local conflict severity for that species, which can be influenced by economic and political situations

371 (Loch, Marmontel \& Simões-Lopes, 2009; Alves, Zappes \& Andriolo., 2012). In our Juruá 372 waterscape where piracatinga fisheries are not of commercial importance, both the boto and 373 tucuxi were always reportedly released. The situation in Peru is more complex, with most fishers 374 releasing entangled botos and tucuxis, but some ports displaying a higher frequency of use for 375 bait (Campbell et al., 2020). 
377

378

379

380

381

382

383

384

385

386

387

388

389

390

391

392

393

394

395

396

397

398

399

400

401

402

403

404

405

406

\section{Body Mass and Conflict Severity}

The positive relationship that we found between body mass and conflict severity supports the similar finding of Inskip and Zimmermann (2009), who examined conflict severity with felids, emphasising the need for greater conservation attention on larger bodied species. Our results also agree with previous studies that find large-bodied species or individuals, such as male crocodilians, are often engaged in more severe conflicts and represent a greater threat to human life (Caldicott et al., 2015; Campbell et al., 2013; Fukuda et al., 2015). The strong pattern in our results can also be considered a conservative assessment, as we used average female body mass for crocodilians, from Lakin et al. (2020), rather than maximum reported body mass. Using maximum body mass would exaggerate the strength of the relationship, as male crocodilians can achieve much larger body masses.

A possible limitation of our method is the focus on attacks on humans, as this trend is largely influenced by crocodilians. For instance, of the 26 recognised crocodilian species, 15 have been documented to attack humans, seven of which were responsible for lethal attacks (Sideleau \& Britton, 2013). In comparison, otters rarely attack humans, with $95.2 \%$ of documented cases in Belanger et al. (2011) linked to the North American river otter, and we could find no cases of cetacean attacks. We were unable to quantify other types of conflict such as entanglement rate or fish depredation as part of a repeatable method to calculate conflict severity. For some species, such as the boto, this may have led to assigning a low conflict severity category overall despite the occurrence of more severe conflicts in some localities (Loch, Marmontel \& Simões-Lopes, 2009; Alves, Zappes \& Andriolo, 2012).

\section{IUCN Red List Status and Conflict Severity}

We found species in lower threat categories on the IUCN Red List displayed higher levels of conflict with humans. This finding has important management considerations for species found in lower threat categories, or those that are recovering in population size and increasingly experiencing conflict. Coexistence with recovering species can depend on perceived or actual population trends, and the conservation strategies used to manage conflict (Brackhane et al., 2018; Fukuda et al., 2019; Patro \& Padhi et al., 2019; Fukuda et al., 2020). For instance, in our Amazonian case study, where black caiman and giant otter populations have increased 
407 following declines from peak levels of historical hunting (Antunes et al., 2016), 14.6\% of 408 interviewees reported that coexistence with these species depends on their future population 409 trends (Lima, Marmontel \& Bernard, 2014a; Pimenta et al., 2018; Marioni et al., 2021).

410 The relationship we found between threatened status and conflict severity is likely driven 411 by the studies on crocodilians, with a high number of studies on common and widespread 412 species, but with several rarer species poorly studied and/or with no documentation of conflicts.

413 Threatened species across all taxonomic groups may suffer a bias in reduced reporting of 414 conflicts as they occupy limited ranges or occur in particular countries (Sideleau \& Britton, 415 2013). The approach adopted in our study is suitable for investigating broad scale patterns across 416 species at a large-scale but is less likely to identify differences in conflict severity that may 417 influence species populations at the local level, such as the higher severity of saltwater crocodile 418 conflicts in Timor-Leste compared to Australia (Fukuda, Manolis \& Appel, 2014; Brackhane et 419 al. 2018; Fukuda et al., 2020). We therefore advise caution in the interpretation of some aspects 420 of our results for such threatened species, as even minimal conflict could have a

421 disproportionately higher effect due to their inherent rarity.

422

\section{Research Needs and Limitations}

425

426

427

428

429

430

431

432

433

434

435

436

437
In our case study, we used binary question answers to assess conflicts, but a more quantitative approach e.g. quantifying the financial cost of net damage to each fisher could have improved the scope for analysing different predictors of conflict severity. Anecdotally, from our review we noticed that few studies quantify conflicts, as with our case study, but such quantification would improve the value and impact of studies. Increased availability of data in the literature regarding the occurrence of entanglement in fishing nets, and economic losses due to net damage, would have strengthened the analyses possible from our review. In the absence of such data, we necessarily defined conflict severity based solely using attacks. Such an approach did not quantify other forms of conflict which could still generate high conflict severity and have potential impacts for both the conflict species and fishers. This will have biased our measure of severity towards crocodilians and therefore had an impact on our broad scale analysis.

Our review indicates that conflicts with the majority of crocodilians, cetaceans and otters have been infrequently documented in the literature and there is a need for wider systematic reporting, particularly for species experiencing high levels of conflict. Our focus on the 
438 frequency of studies, which is an approximate measure of how well studied a species or topic 439 might be and does not take into account the quality or impact of each study. Our exclusion of 440 grey literature and non-English language publications, and our decision not to conduct searches 441 using Web of Science, may also have precluded additional studies being located (Haddaway et $442 a l ., 2015)$ and led to the possible omission of some useful information (Inskip and Zimmermann, 443 2009). Despite these potential limitations, the quantitative assessment in our study provides a 444 valuable contribution to address the poor understanding of human-wildlife conflicts in aquatic 445 systems both in the Amazon and across the tropics.

446

\section{Conclusions}

Simultaneously conducting our case study and literature review has allowed us to identify 449 local and broad scale patterns of human-wildlife conflict with crocodilians, cetaceans and otters.

450

451

452

453

454

455

456

457

458

459

460

461

462

463

\section{Acknowledgements}

465

466

467 Groenendijk for allowing us to use their photographs of black caiman and giant otter, and Sannie Multiple factors may influence conflict severity including species body mass or rarity, but better estimations of conflict severity are required, by integrating forms of conflict other than attacks into calculations. The dual nature of our research allows us to make the following recommendations for future research in aquatic systems to better prioritise conflict resolution efforts. Our main recommendations for field studies are to: (1) quantify the economic costs of conflicts, for example damage to gill-nets, at the fisher level; (2) identify the types of fishing equipment used; (3) quantify the entanglement rate per fisher, for different types of fishing equipment; and (4) directly quantify the attack rate per fisher. Future research at a broader scale should focus on (1) determining the severity of any conflicts for species identified here as infrequently or rarely documented, with priority given to those identified as experiencing a more severe level of conflict; (2) assessing conflict resolution techniques to determine their effectiveness; (3) conducting a meta-analysis of economic losses due to net damage and fish depredation; and (4) conducting a meta-analysis of entanglement in fishing equipment.

We are grateful to Franciney Silva da Souza for assisting fieldwork and to all reserve residents for their hospitality and participation in interviews. We wish to thank Frank Hajek and Jessica 
468 Brum for photographs of the boto and tucuxi. This publication is part of the Instituto Juruá series 469 (www.institutojurua.org.br).

470

471

472

473

474

475

476

477

478

479

480

481

482

483

484

485

486

487

488

489

490

491

492

493

494

495

496

497

498

\section{References}

Alves, L.C.P.D.S., Zappes, C.A., Andriolo, A., 2012. Conflicts between river dolphins (Cetacea: Odontoceti) and fisheries in the central Amazon: a path toward tragedy? Zoologia, 29(5), pp. 420-429 DOI: 10.1590/S1984-46702012000500005.

Anderson, R.C., Herrera, M., Ilangakoon, A.D., Koya, K.M., Moazzam, M., Mustika, P.L. and Sutaria, D.N., 2020. Cetacean bycatch in Indian Ocean tuna gillnet fisheries. Endangered Species Research, 41, pp. 39-53, DOI: 10.3354/esr01008.

Antunes, A.P., Fewster, R.M., Venticinque, E.M., Peres, C.A., Levi, T., Rohe, F., Shepard, G.H., 2016. Empty forest or empty rivers? A century of commercial hunting in Amazonia. Science Advances, 2, e1600936. DOI: 10.1126/sciadv.1600936.

Aust, P., Boyle, B., Fergusson, R., Coulson, T. 2009. The impact of Nile crocodiles on rural livelihoods in northeastern Namibia. South African Journal of Wildlife Research, 39(1), pp. 57-69. DOI: 10.3957/056.039.0107.

Barbieri, F., Machado, R., Zappes, C.A., Oliveira, L.R.D., 2012. Interactions between the Neotropical otter (Lontra longicaudis) and gillnet fishery in the southern Brazilian coast. Ocean and Coastal Management, 63, pp. 16-23. DOI: 10.1016/j.ocecoaman.2012.03.007

Batista, V S., Inhamuns, A. J., Freitas, C.E.C., Freire-Brasil, D., 1998. Characterisation of the fishery in riverine communities in the Low-Solimões/High-Amazon region. Fisheries Management Ecology, 5, pp. 101-117.

Begossi, A., Salivonchyk, S.V., Hallwass, G., Hanazaki, N., Lopes, P.F.M., Silvano, R.A.M., Dumaresq, D., Pittock, J., 2018. Fish consumption on the Amazon: a review of biodiversity, hydropower and food security issues. Brazilian Journal of Biology, 79, pp. 345-357. DOI: 10.1590/1519-6984.790118.

Belanger, M., Clough, N., Askin, N., Tan, L., Wittnich, C., 2011. A review of violent or fatal otter attacks. IUCN Otter Specialist Group Bulletin. 28 (1), pp.11-16.

Brackhane, S., Webb, G., Xavier, F.M., Gusmao, M., Pechacek, P., 2018. When conservation becomes dangerous: human-crocodile conflict in Timor-Leste. The Journal of Wildlife Management, 82(7), pp. 1332-1344. DOI: 10.1002/jwmg.21497. 
499 Brum, S., Rosas-Ribeiro, P., Amaral, R.D.S., de Souza, D.A., Castello, L., da Silva, V.M.F.,

500

501

502

503

504

505

506

507

508

509

510

511

512

513

514

515

516

517

518

519

520

521

522

523

524

525

526

527

528

2021. Conservation of Amazonian aquatic mammals. Aquatic Conservation: Marine and Freshwater Ecosystems, 31(5), pp. 1068-1086. DOI: 10.1002/aqc.3590.

Cabral, M.M., Zuanon, J., de Mattos, G.E., Rosas, F.C., 2010. Feeding habits of giant otters Pteronura brasiliensis (Carnivora: Mustelidae) in the Balbina hydroelectric reservoir, central Brazilian Amazon. Zoologia, 27(1), pp. 47-53.

Caldicott, D.G., Croser, D., Manolis, C., Webb, G., Britton, A., 2005. Crocodile attack in Australia: an analysis of its incidence and review of the pathology and management of crocodilian attacks in general. Wilderness and Environmental Medicine, 16(3), pp. 143159. DOI: 10.1580/1080-6032(2005)16[143:CAIAAA]2.0.CO;2.

Campbell, E., Mangel, J.C., Alfaro-Shigueto, J., Mena, J.L., Thurstan, R.H., Godley, B.J., 2020. Coexisting in the Peruvian Amazon: Interactions between fisheries and river dolphins. Journal for Nature Conservation, 56, 125859. DOI: 10.1016/j.jnc.2020.125859.

Campbell, H.A., Dwyer, R.G., Irwin, T.R., Franklin, C.E., 2013. Home range utilisation and long-range movement of estuarine crocodiles during the breeding and nesting season. PLoS One, 8, e62127. DOI: 10.1371/journal.pone.0062127.

Campos-Silva, J.V., Hawes, J.E., Andrade, P.C., Peres, C.A., 2018. Unintended multispecies cobenefits of an Amazonian community-based conservation programme. Nature Sustainability, 1(11), pp. 650-656. DOI: 10.1038/s41893-018-0170-5.

Campos-Silva, J.V., Peres, C.A., 2016. Community-based management induces rapid recovery of a high-value tropical freshwater fishery. Scientific Reports, 6(1), pp. 1-13. DOI: $10.1038 /$ srep34745.

Choudhary, S.K., Smith, B.D., Dey, S., Dey, S., Prakash, S., 2006. Conservation and biomonitoring in the Vikramshila gangetic dolphin sanctuary, Bihar, India. Oryx, 40(2), pp. 189-197. DOI: 10.1017/S0030605306000664.

da Silva, V.M.F., Best, R.C., 1996. Freshwater dolphin/fisheries interaction in the central Amazon (Brazil). Amazoniana. Kiel, 14(1), pp. 165-175.

da Silva, V.M.F., Freitas, C.E.C., Dias, R.L., Martin, A.R., 2018. Both cetaceans in the Brazilian Amazon show sustained, profound population declines over two decades. PloS one, 13(5), e0191304. DOI: 10.1371/journal.pone.0191304.

Peer] reviewing PDF | (2021:05:61479:2:0:NEW 28 Nov 2021) 
529 Dickman, A.J., 2010. Complexities of conflict: the importance of considering social factors for

530

531

532

533

534

535

536

537

538

539

540

541

542

543

544

545

546

547

548

549

550

551

552

553

554

555

556

557

558 effectively resolving human-wildlife conflict. Animal Conservation, 13(5), pp. 458-466. DOI: $10.1111 / j .1469-1795.2010 .00368 . x$.

Dudgeon, D., Arthington, A.H., Gessner, M.O., Kawabata, Z.I., Knowler, D.J., Lévêque, C., Naiman, R.J., Prieur-Richard, A., Soto, D., Stiassny, M.L.J., Sullivan, C.A., 2006. Freshwater biodiversity: importance, threats, status and conservation challenges. Biological Reviews, 81(2), pp. 163-182. DOI: 10.1017/S1464793105006950.

Endo, W., Peres, C.A., Haugaasen, T., 2016. Flood pulse dynamics affects exploitation of both aquatic and terrestrial prey by Amazonian floodplain settlements. Biological Conservation, 201, pp. 129-136. DOI: 10.1016/j.biocon.2016.07.006.

ESRI, 2014. ArcGIS Desktop.

Fonseca, V., Marmontel, M., 2011. Local knowledge and conflicts with otters in western Brazilian Amazon: a preliminary report. IUCN Otter Specialists Group Bulletin, 28(B), pp. 64-68.

Fukuda, Y., Manolis, C., Appel, K., 2014. Featured article: management of human-crocodile conflict in the Northern Territory, Australia: review of crocodile attacks and removal of problem crocodiles. The Journal of Wildlife Management, 78(7), pp. 1239-1249. DOI: 10.1002/jwmg.767.

Fukuda, Y., Manolis, C., Saalfeld, K., Zuur, A., 2015. Dead or alive? Factors affecting the survival of victims during attacks by saltwater crocodiles (Crocodylus porosus) in Australia. PLoS One, 10(5), e0126778. DOI: 10.1371/journal.pone.0126778.

Fukuda, Y., Webb, G., Edwards, G., Saalfeld, K., Whitehead, P., 2020. Harvesting predators: simulation of population recovery and controlled harvest of saltwater crocodiles Crocodylus porosus. Wildlife Research, 48(3), pp. 252-263. DOI: 10.1071/WR20033.

Fukuda, Y., Webb, G., Manolis, C., Lindner, G., Banks, S., 2019. Translocation, genetic structure and homing ability confirm geographic barriers disrupt saltwater crocodile movement and dispersal. PloS one, 14(8), e0205862. DOI:

10.1371/journal.pone.0205862.

Gopi, G. V., Pandav, B., 2009. Humans sharing space with Crocodylus porosus in Bhitarkanika wildlife sanctuary: conflicts and options. Current Science, 96(4), pp. 459-460. 
559 Groenendijk, J., Hajek, F., Johnson, P.J., Macdonald, D.W., Calvimontes, J., Staib, E., Schenck,

560

561

562

563

564

565

566

567

568

569

570

571

572

573

574

575

576

577

578

579

580

581

582

583

584

585

586

587

588

589 C., 2014. Demography of the giant otter (Pteronura brasiliensis) in Manu national park, south-eastern Peru: implications for conservation. PLOS One, 9(8), e106202. DOI: 10.1371/journal.pone.0106202.

Haddaway, N.R., Collins, A.M., Coughlin, D., Kirk, S., 2015. The role of Google Scholar in evidence reviews and its applicability to grey literature searching. PloS one, 10(9), p.e0138237.

Hawes, J.E., Peres, C.A., Riley, L.B., Hess, L.L., 2012. Landscape-scale variation in structure and biomass of Amazonian seasonally flooded and unflooded forests. Forest Ecology and Management, 281, pp. 163-176. DOI: 10.1016/j.foreco.2012.06.023.

He, F., Zarfl, C., Bremerich, V., David, J.N., Hogan, Z., Kalinkat, G., Tockner, K., Jähnig, S.C., 2019. The global decline of freshwater megafauna. Global Change Biology, 25(11), pp. 3883-3892. DOI: $10.1111 / \mathrm{gcb} .14753$.

Huang, S.L., Hao, Y., Mei, Z., Turvey, S. T., Wang, D., 2012. Common pattern of population decline for freshwater cetacean species in deteriorating habitats. Freshwater Biology, 57(6), pp. 1266-1276. DOI: 10.1111/j.1365-2427.2012.02772.x.

Hunter, L., 2011. Carnivores of the World. Princeton: Princeton University Press.

IBM Corporation. 2014. SPSS Statistics.

Inskip, C., Zimmermann, A., 2009. Human-felid conflict: a review of patterns and priorities worldwide. Oryx, 43(1), pp. 18-34. DOI: 10.1017/S003060530899030X.

IUCN, 2020. The IUCN red list of threatened species, IUCN, viewed 20 December 2020, < https://www.iucnredlist.org/>.

Jaramillo-Legorreta, A.M., Cardenas-Hinojosa, G., Nieto-Garcia, E., Rojas-Bracho, L., Thomas, L., Ver Hoef, J.M., Moore, J., Taylor, B., Barlow, J., Tregenza, N., 2019. Decline towards extinction of Mexico's vaquita porpoise (Phocoena sinus). Royal Society Open Science, 6(7), p.190598. DOI: 10.1098/rsos.190598.

Junk, W.J., 1984. Ecology, fisheries and fish culture in Amazonia. In: H. Sioli, ed. The Amazon. Netherlands: Springer, pp. 443-476.

Junk, W.J., Piedade, M.T.F., Schöngart, J., Cohn-Haft, M., Adeney, J.M., Wittmann, F., 2011. A classification of major naturally-occurring Amazonian lowland wetlands. Wetlands, 31(4), pp. 623-640.

Peer] reviewing PDF | (2021:05:61479:2:0:NEW 28 Nov 2021) 
590 Kelkar, N., Krishnaswamy, J., Choudhary, S., Sutaria, D., 2010. Coexistence of fisheries with

591

592

593

594

595

596

597

598

599

600

601

602

603

604

605

606

607

608

609

610

611

612

613

614

615

616

617

618

619 river dolphin conservation. Conservation Biology, 24(4), pp. 1130-1140. DOI: 10.1111/j.1523-1739.2010.01467.x.

Lakin, R.J., Barrett, P.M., Stevenson, C., Thomas, R.J., Wills, M.A., 2020. First evidence for a latitudinal body mass effect in extant Crocodylia and the relationships of their reproductive characters. Biological Journal of the Linnean Society, 129(4), pp. 875-887. DOI: 10.1093/biolinnean/blz208.

Leatherwood, S., Reeves, R.R., 1994. River dolphins: a review of activities and plans of the cetacean specialist group. Aquatic Mammals, 20, pp. 137-154.

Lima, D.S., Marmontel, M., Bernard, E., 2014a. Conflicts between humans and giant otters (Pteronura brasiliensis) in Amanã reserve, Brazilian Amazonia. Ambiente and Sociedade, 17(2), pp. 127-142. DOI: 10.1590/S1414-753X2014000200009.

Lima, D.S., Marmontel, M., Bernard, E., 2014b. Reoccupation of historical areas by the endangered giant river otter Pteronura brasiliensis (Carnivora: Mustelidae) in Central Amazonia, Brazil. Mammalia, 78(2), pp. 177-184. DOI: 10.1515/mammalia-2013-0023.

Loch, C., Marmontel, M., Simões-Lopes, P.C., 2009. Conflicts with fisheries and intentional killing of freshwater dolphins (Cetacea: Odontoceti) in the western Brazilian Amazon. Biodiversity and Conservation, 18(14), pp. 3979-3988. DOI: 10.1007/s10531-009-96934.

Macdonald, D.W., 2009. The Encyclopaedia of Mammals. Oxford: Oxford University Press. Mangel, J.C., Alfaro-Shigueto, J., Witt, M.J., Hodgson, D.J., Godley, B.J., 2013. Using pingers to reduce bycatch of small cetaceans in Peru's small-scale driftnet fishery. Oryx, 47(4), pp. 595-606, DOI: 10.1017/S0030605312000658.

Marioni, B., Barão-Nóbrega, J.A.L., Botero-Arias, R., Muniz, F., Campos, Z., Da Silveira, R., Magnusson, W.E., Villamarín, F., 2021. Science and conservation of Amazonian crocodilians: a historical review. Aquatic Conservation: Marine and Freshwater Ecosystems, 31(5), pp. 1056-167. DOI: 10.1002/aqc.3541.

Martin, A.R., Da Silva, V.M.F., 2004. River dolphins and flooded forest: seasonal habitat use and sexual segregation of botos (Inia geoffrensis) in an extreme cetacean environment. Journal of Zoology, 263(3), pp.295-305. 
620 Michalski, F., Conceição, P.C., Amador, J.A., Laufer, J., Norris, D. 2012. Local perceptions and

621

622

623

624

625

626

627

628

629

630

631

632

633

634

635

636

637

638

639

640

641

642

643

644

645

646

647

648

649 implications for giant otter (Pteronura brasiliensis) conservation around protected areas in the eastern Brazilian Amazon. IUCN Otter Specialist Group Bulletin, 29(1), pp. 34-45.

Newton, P., Endo, W., Peres, C.A., 2012. Determinants of livelihood strategy variation in two extractive reserves in Amazonian flooded and unflooded forests. Environmental Conservation, 39(2), pp. 97-110. DOI: 10.1017/S0376892911000580.

Patro, S., Padhi, S.K., 2019. Saltwater crocodile and human conflict around Bhitarkanika National Park, India: a raising concern for determining conservation limits. Ocean \& Coastal Management, 182, 104923. DOI: 10.1016/j.ocecoaman.2019.104923.

Pekel, J.F., Cottam, A., Gorelick, N., Belward, A.S., 2016. High-resolution mapping of global surface water and its long-term changes. Nature, 540(7633), pp. 418-422. DOI: 10.1038/nature20584.

Peres, C.A., Carkeek, A.M. 1993. How caimans protect fish stocks in western Brazilian Amazonia - a case for maintaining the ban on caiman hunting. Oryx, 27(4), pp. 225-230.

Pimenta, N.C., Gonçalves, A.L.S., Shepard, G.H., Macedo, V.W., Barnett, A.P.A., 2018. The return of giant otter to the Baniwa Landscape: A multi-scale approach to species recovery in the middle Içana River, Northwest Amazonia, Brazil. Biological Conservation, 224, pp. 318-326. DOI: 10.1016/j.biocon.2018.06.015.

Pimm, S.L., Raven, P., 2000. Biodiversity: extinction by numbers. Nature, 403(6772), pp. 843845. DOI: $10.1038 / 35002708$.

Platt, S.G., Thorbjarnarson, J.B., 2000. Status and conservation of the American crocodile, Crocodylus acutus, in Belize. Biological Conservation, 96(1), pp. 13-20. DOI: 10.1016/S0006-3207(00)00038-0.

Pooley, S., Botha, H., Combrink, X., Powell, G., 2020. Synthesizing Nile crocodile Crocodylus niloticus attack data and historical context to inform mitigation efforts in South Africa and eSwatini (Swaziland). Oryx, 54(5), pp.629-638. DOI: 10.1017/S0030605318001102.

Prajith, K.K., Das, P.D., Edwin, L., 2014. Dolphin Wall Net (DWN)-an innovative management measure devised by ring seine fishermen of Kerala-India to reducing or eliminating marine mammal-fishery interactions. Ocean \& Coastal Management, 102, pp. 1-6, DOI: 10.1016/j.ocecoaman.2014.08.012. 
650 R Core Team, 2021. R: A language and environment for statistical computing. R Foundation for

651

652

653

654

655

656

657

658

659

660

661

662

663

664

665

666

667

668

669

670

671

672

673

674

675

676

677

678 Statistical Computing, Vienna, Austria. <https://www.R-project.org/>.

Recharte, M., Bowler, M., Bodmer, R., 2009. Potential conflict between fishermen and giant otter (Pteronura brasiliensis) populations by fishermen in response to declining stocks of arowana fish (Osteoglossum bicirrhosum) in northeastern Peru. IUCN Otter Specialist Group Bulletin, 25(2), pp. 89-93.

Rio, C.M.D., Dugelby, B., Foreman, D., Miller, B., Noss, R. and Phillips, M., 2001. The importance of large carnivores to healthy ecosystems. Endangered Species Update, 18, 202.

Rosas-Ribeiro, P.F., Rosas, F.C.W., Zuanon, J., 2012. Conflict between giant otter and fishermen Pteronura brasiliensis in western Brazilian Amazon. Biotropica, 44(3), pp. 437-444. DOI: $10.1111 / \mathrm{j} .1744-7429.2011 .00828 . x$.

Santos, G., Ferreira, E., Zuanon, J., 2006. Peixes Comerciais de Manaus. Manaus: IBAMA, ProVárzea.

Scott, R., Scott, H., 1994. Crocodile bites and traditional beliefs in Korogwe District, Tanzania. British Medical Journal, 309, pp. 1691-1692. DOI: 10.1136/bmj.309.6970.1691.

Sideleau, B., Britton, A.R.C. 2013. An analysis of crocodilian attacks worldwide for the period of 2008 - July 2013. Crocodiles. Proceedings of the 22nd Working Meeting of the IUCNSSC Crocodile Specialist Group. IUCN: Gland, Switzerland, pp.110-113.

Sinha, R.K., 2002. An alternative to dolphin oil as a fish attractant in the Ganges river system: conservation of the Ganges river dolphin. Biological Conservation, 107(2), pp. 253-257. DOI: 10.1016/S0006-3207(02)00058-7.

Snape, R.T.E., Broderick, A.C., Çiçek, B.A., Fuller, W.J., Tregenza, N., Witt, M.J., Godley, B.J., 2018. Conflict between dolphins and a data-scarce fishery of the European Union. Human Ecology, 46(3), pp. 423-433. DOI: 10.1007/s10745-018-9989-7.

Tixier, P., Lea, M.A., Hindell, M.A., Welsford, D., Mazé, C., Gourguet, S., Arnould, J.P., 2021. When large marine predators feed on fisheries catches: Global patterns of the depredation conflict and directions for coexistence. Fish and Fisheries, 22(1), pp. 31-53. DOI: 10.1111/faf.12504. 
679 Treves, A., Karanth, K.U., 2003. Human-carnivore conflict and perspectives on carnivore

680

681

682

683

684

685

686

687

688

689

690

691

692

693

694

695

696

697

698

699

700

701 management worldwide. Conservation Biology, 17(6), pp. 1491-1499. DOI: 10.1111/j.1523-1739.2003.00059.x.

Turvey, S.T., Pitman, R.L., Taylor, B.L., Barlow, J., Akamatsu, T., Barrett, L.A., Zhao, X., Reeves, R.R., Stewart, B.S., Wang, K., Wei, Z., Zhang, X., Pusser, L.T., Richlen, M., Brandon, J.R., Wang, D., 2007. First human-caused extinction of a cetacean species? Biology Letters, 3(5), pp. 537-540. DOI: 10.1098/rsbl.2007.0292.

Waples, D.M., Thorne, L.H., Hodge, L.E., Burke, E.K., Urian, K.W., Read, A.J., 2013. A field test of acoustic deterrent devices used to reduce interactions between bottlenose dolphins and a coastal gillnet fishery. Biological Conservation, 157, pp. 163-171. DOI: 10.1016/j.biocon.2012.07.012.

Woodroffe, R., Ginsberg, J.R., 1998. Edge effects and the extinction of populations inside protected areas. Science, 280, pp. 2126-2128. DOI: 10.1126/science.280.5372.2126.

Zanon. S, 2021. Tucuxi na lista vermelha: todos os botos de rio do mundo agora ameaçados, Mongabay, viewed 15/4/21, <https://brasil.mongabay.com/2021/04/tucuxi-na-listavermelha-todos-os-botos-de-rio-do-mundo-agora-ameacados/>.

Zhang, X., Wang, D., Liu, R., Wei, Z., Hua, Y., Wang, Y., Chen, Z., Wang, L., 2003. The Yangtze river dolphin or baiji (Lipotes vexillifer): population status and conservation issues in the Yangtze river, China. Aquatic Conservation: Marine and Freshwater Ecosystems, 13(1), pp. 51-64. DOI: 10.1002/aqc.547.

Zhou, K., Sun, J., Gao, A., Würsig, B., 1998. Baiji (Lipotes vexillifer) in the lower Yangtze river: movements, numbers threats and conservation needs. Aquatic Mammals, 24 (2), pp. $123-$ 132. 


\section{Figure 1}

Map showing the location of the focal study landscape in the Médio Juruá region of western Brazilian Amazonia.

Interviews were conducted in local communities (black dots) along the Juruá River (blue line) within two sustainable-use reserves (light green polygons). Made with Natural Earth. Free vector and raster map data @ naturalearthdata.com. 


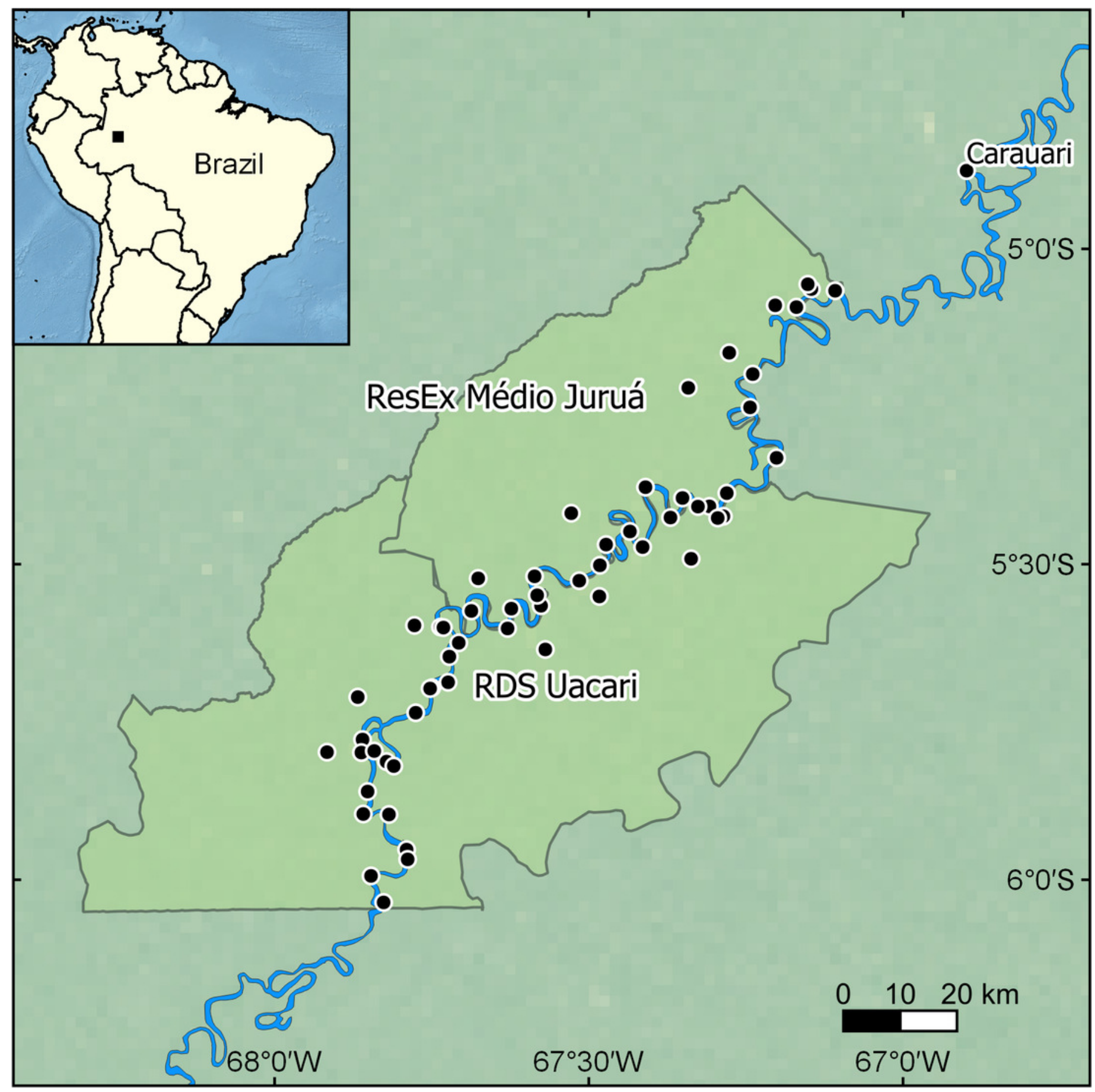




\section{Figure 2}

The four 'problem species' in the mid-Juruá.

A) black caiman, B) giant otter, C) boto and D) tucuxi. Photo credits: A and B) Jessica Groenendijk, C and D) Sannie Brum.

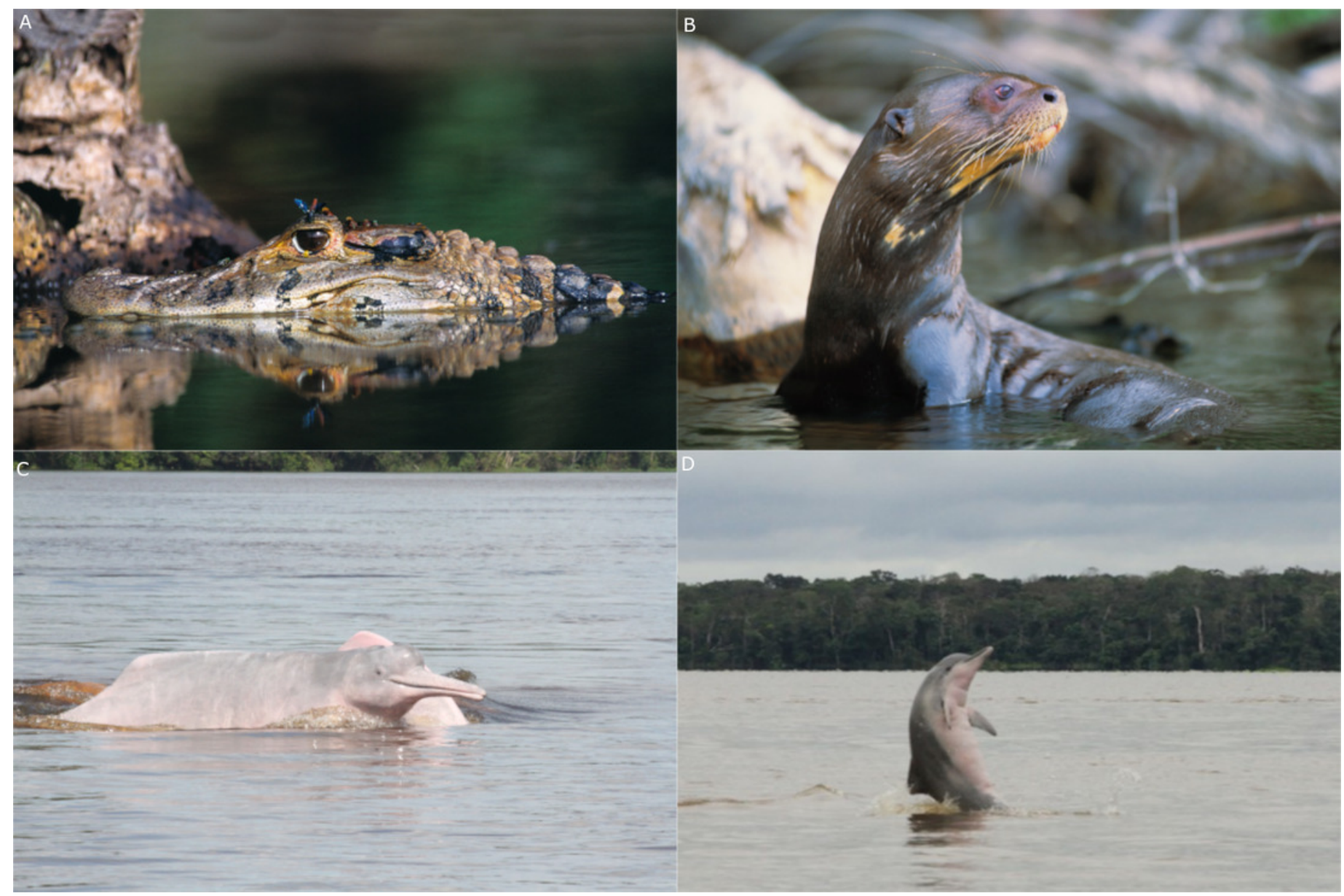


Figure 3

Percent of interviewees $(n=49)$ who indicated that each of four species of causes problems in general, damage fishing equipment, frightens away fish, or becomes entangled in nets.

The species are black caiman ( $\mathrm{C}$, black bars), giant otter $(\mathrm{O}$, dark grey bars), boto ( $\mathrm{B}$, light grey bars) and tucuxi ( $T$, white bars). 


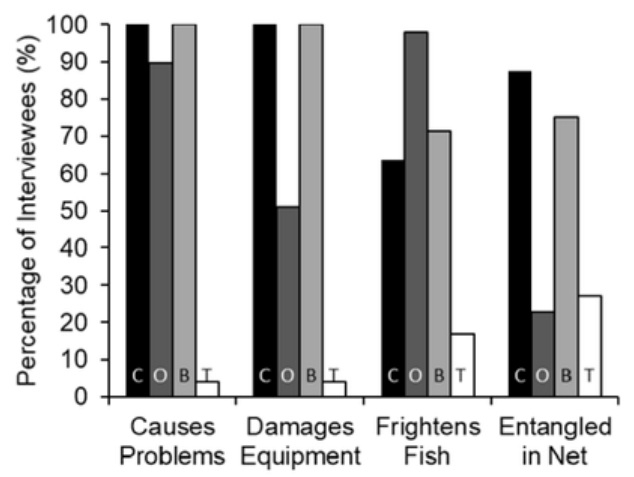


Figure 4

Percent of interviewees $(n=49)$ who indicated the potential outcomes of entanglement in fishing nets by four species of piscivorous mammals and reptiles.

Outcomes are being killed by fishers (black), dying without fisher intervention (dark grey), being released by fishers (light grey) or escaping without fisher intervention (white). 


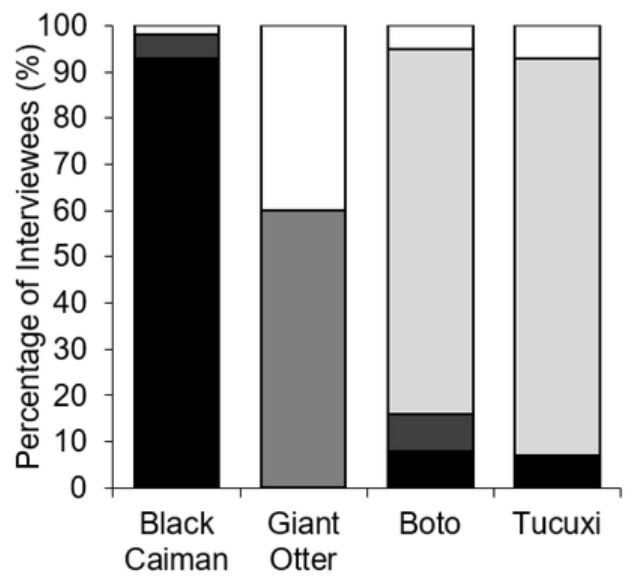


Figure 5

Number of human-wildlife conflict studies concerning crocodilians, cetaceans and otters over time (1962-2020). 


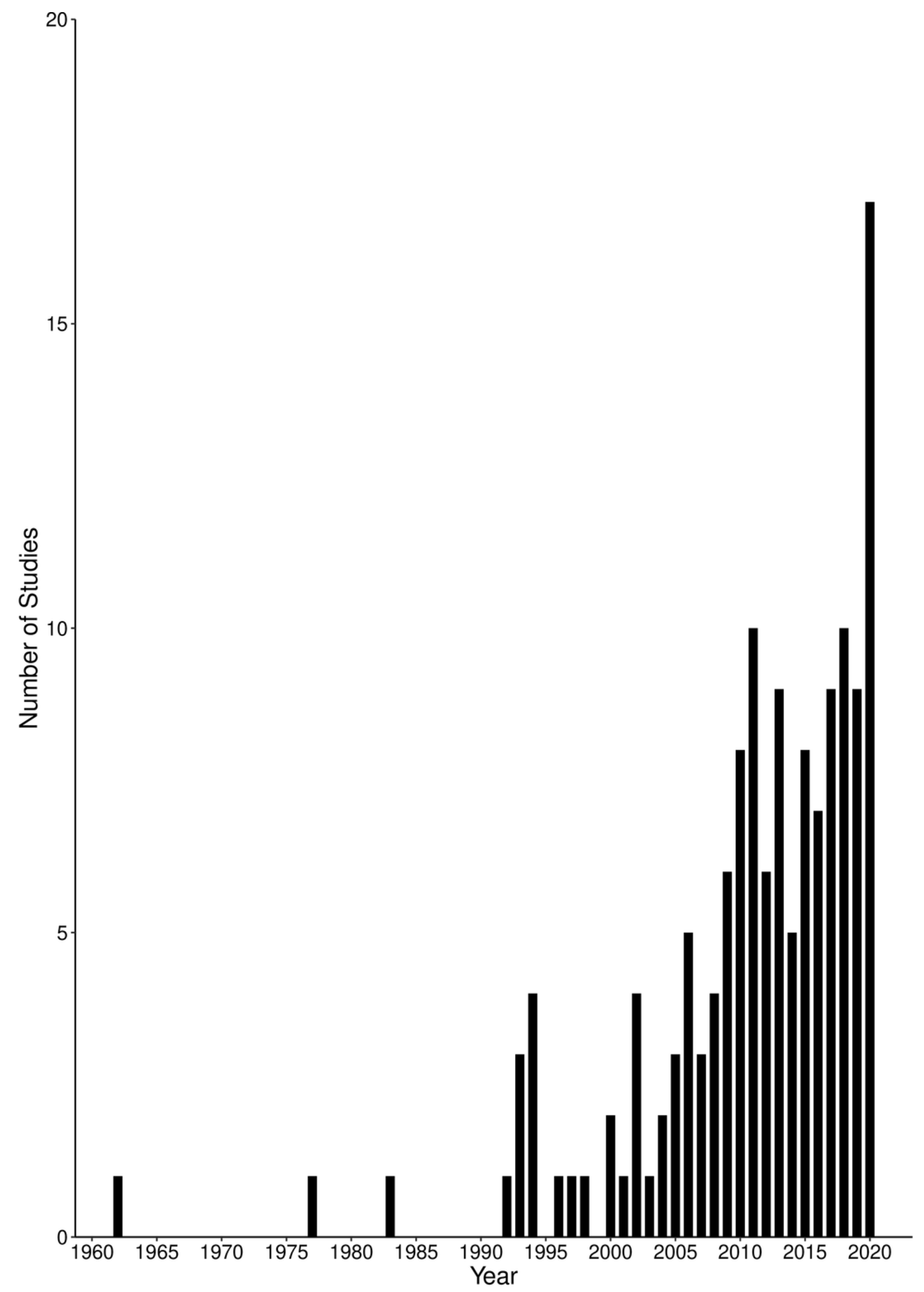




\section{Table $\mathbf{1}$ (on next page)}

Criteria for categories (adapted from Inskip and Zimmermann, 2009) used to determine the severity of conflicts found in the literature review, and the frequency of studies reporting conflicts 
1 Table 1. Criteria for categories (adapted from Inskip and Zimmermann, 2009) used to determine

2 the severity of conflicts found in the literature review, and the frequency of studies reporting

3 conflicts.

\begin{tabular}{ll}
\hline Category & Definition \\
\hline Severity of Conflict & Very high number of documented attacks on people $(>20$ \\
Severe & reported fatalities and/or $>50$ non-fatal attacks $).$ \\
High & High number of documented attacks on people (1-20 \\
& fatalities and/or $10-50$ non-fatal attacks $).$ \\
Moderate & Low number of documented attacks on people (1-9 non- \\
& fatal attacks $).$ \\
Low & No documented attacks on people.* \\
& Other forms of conflict documented in the literature but not \\
& in relation to attacks on people.** \\
No documented attacks on people or evidence of other \\
conflicts. \\
Frequency of Studies
\end{tabular}

4

$5 *$ We defined the number of fatal and non-fatal attacks on humans worldwide by crocodilians

6 between 2008 and 2013 following Sideleau \& Britton (2013); it was not possible to filter the

7 locations of these attacks to just the tropics or subtropics. We defined the number of non-fatal

8 attacks by otters between 2000 and 2009 following Bealanger et al. (2011), filtering the data to

9 the tropics and subtropics. The year of attacks were not provided in either of these studies, and we therefore use the different time periods given for crocodilians and otters.

** Other forms of conflicts may include but are not exclusive to: depredation of fish, damage to fishing gear and entanglement in fishing gear. It was not possible to quantify these types of 
13 conflicts, so we used their documentation in the literature as a substitute. This was only carried 14 out for species with no documented attacks on humans. 


\section{Table 2 (on next page)}

List of crocodilian, cetacean and otter species from tropical and subtropical regions.

For each species, the frequency of conflict studies (literature coverage category, number of primary literature studies mentioning conflict), frequency of conflict study per type of conflict, severity of the human-wildlife conflict, body mass and IUCN Red List category are listed. 
1 Table 2. List of crocodilian, cetacean and otter species from tropical and subtropical regions. For each species, the frequency of

2 conflict studies (literature coverage category, number of primary literature studies mentioning conflict), frequency of conflict study

3 per type of conflict, severity of the human-wildlife conflict, body mass and IUCN Red List category are listed.

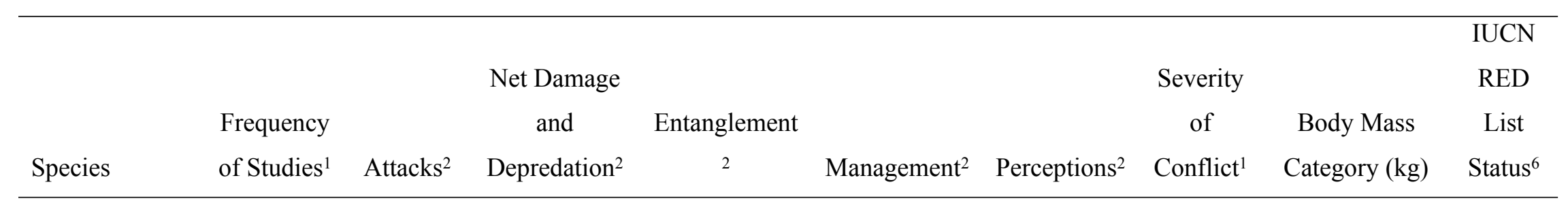

\section{Crocodilians}

African Dwarf

Crocodile

(Osteolaemus

tetraspis)

Rare (1) 0

0

0

0

Low

$10-49^{3}$

VU

American

Alligator

(Alligator

mississippiensi

Frequent

s)

American

Crocodile

(Crocodylus

Frequent

acutus)

(5)

2

0

1

1

1

Severe

$\geq 50^{3}$

VU

Australian

Infrequent

Freshwater

(2)

2

0

0

0

0

Moderat

e $\quad 10-49^{3} \quad$ LC




\begin{tabular}{|c|c|c|c|c|c|c|c|c|c|}
\hline $\begin{array}{l}\text { Crocodile } \\
\text { (Crocodylus } \\
\text { johnstoni) }\end{array}$ & & & & & & & & & \\
\hline Black Caiman & & & & & & & & & \\
\hline (Melanosuchus & & & & & & & & & \\
\hline niger) & $(5)$ & 3 & 1 & 1 & 0 & 1 & High & $\geq 50^{3}$ & $\mathrm{LC}$ \\
\hline Broud-snouted & & & & & & & & & \\
\hline Caiman & & & & & & & & & \\
\hline (Caiman & & & & & & & Moderat & & \\
\hline latirostris) & Rare (1) & 0 & 0 & 0 & 0 & 1 & e & $10-49^{3}$ & $\mathrm{LC}$ \\
\hline Central & & & & & & & & & \\
\hline African & & & & & & & & & \\
\hline $\begin{array}{l}\text { Slender- } \\
\text { snouted }\end{array}$ & & & & & & & & & \\
\hline Crocodile & & & & & & & & & Not \\
\hline (Mecistops & & & & & & & & & assesse \\
\hline leptorhynchus) & DD (0) & 0 & 0 & 0 & 0 & 0 & DD & Not available & d \\
\hline Chinese & & & & & & & & & \\
\hline Alligator & & & & & & & & & \\
\hline (Alligator & & & & & & & & & \\
\hline sinensis) & DD (0) & 0 & 0 & 0 & 0 & 0 & DD & $10-49^{3}$ & $\mathrm{CR}$ \\
\hline Cuban & & & & & & & & & \\
\hline Crocodile & & & & & & & & & \\
\hline (Crocodylus & $\mathrm{DD}(0)$ & 0 & 0 & 0 & 0 & 0 & DD & $\geq 50^{3}$ & $\mathrm{CR}$ \\
\hline
\end{tabular}




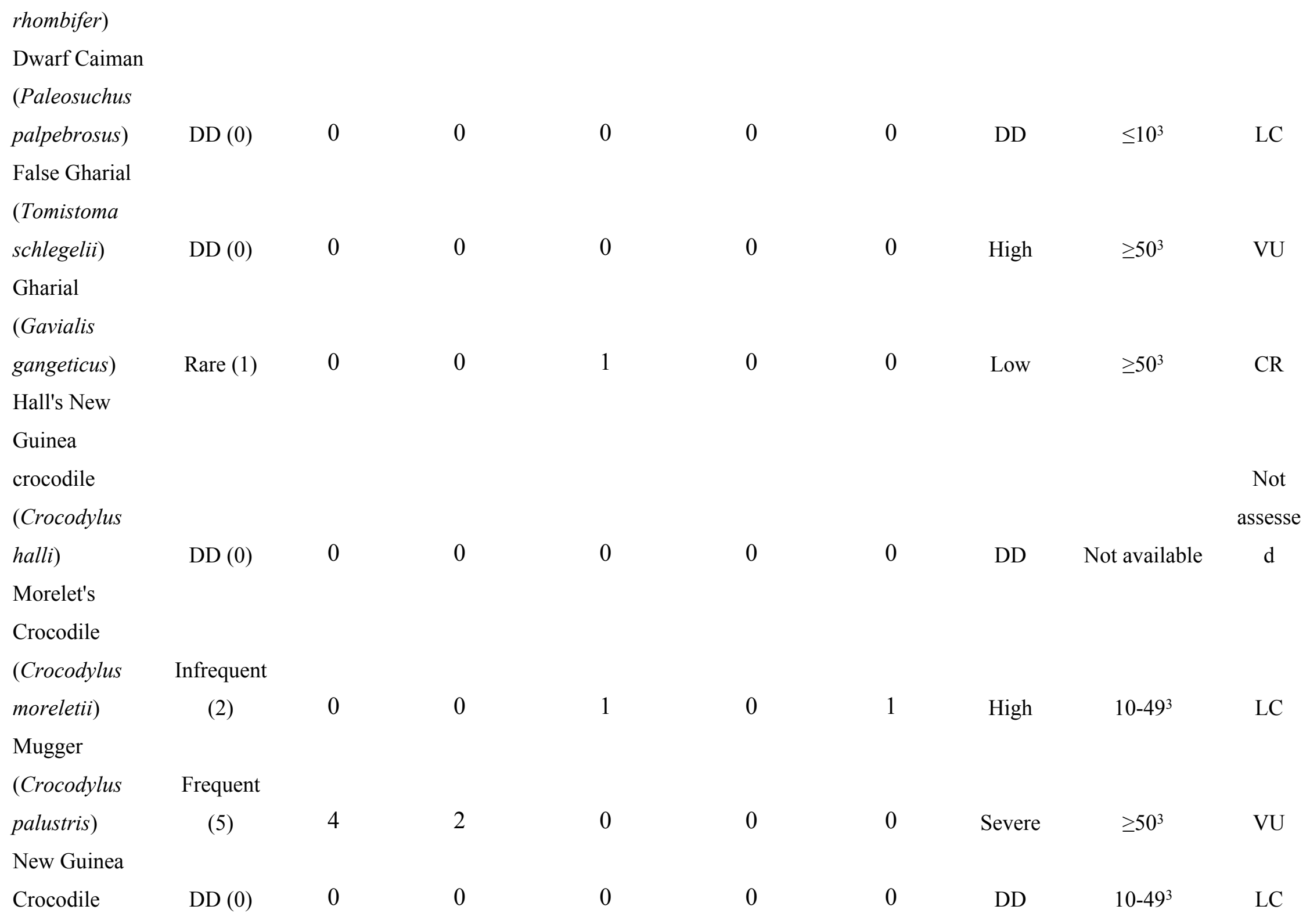




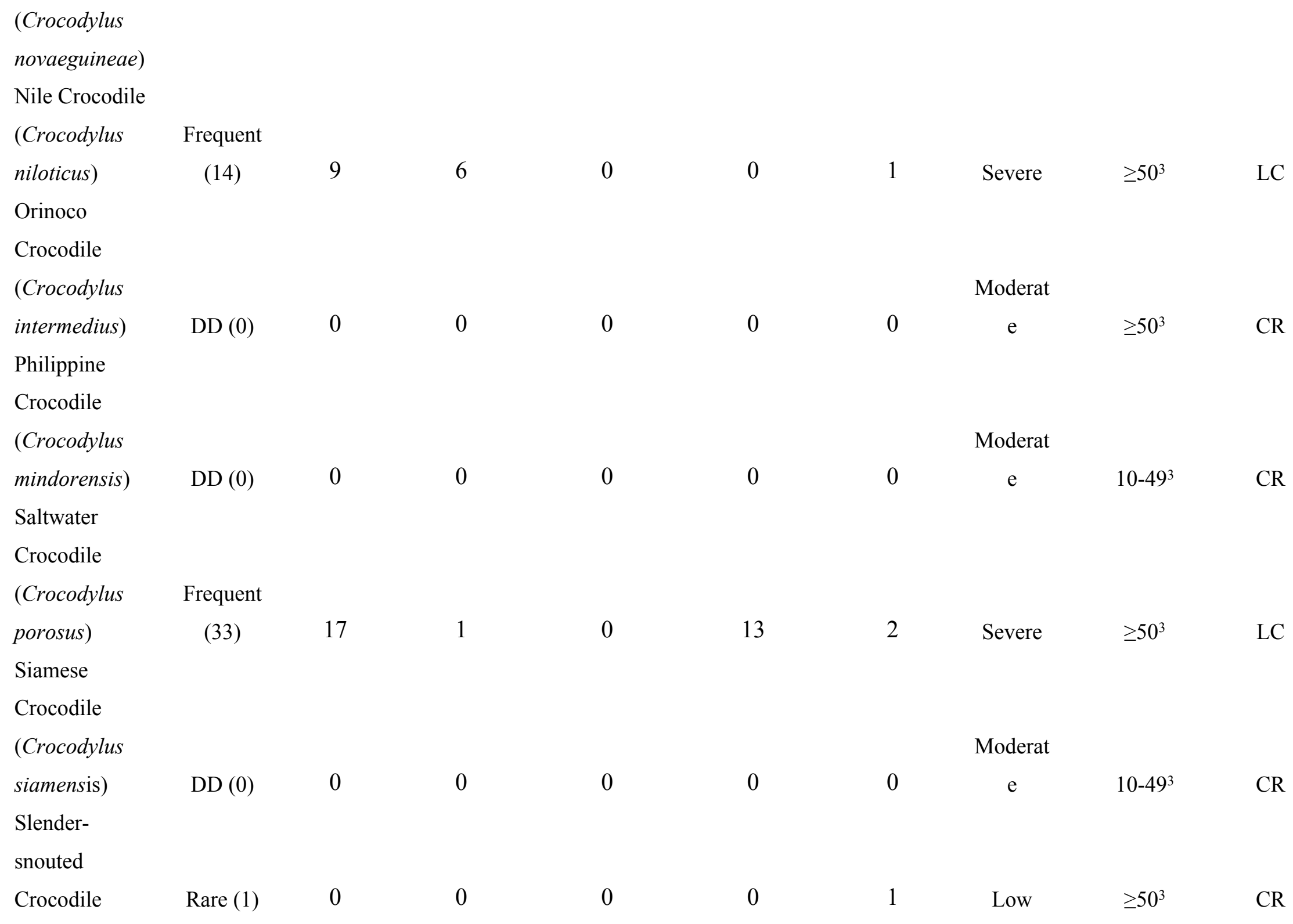




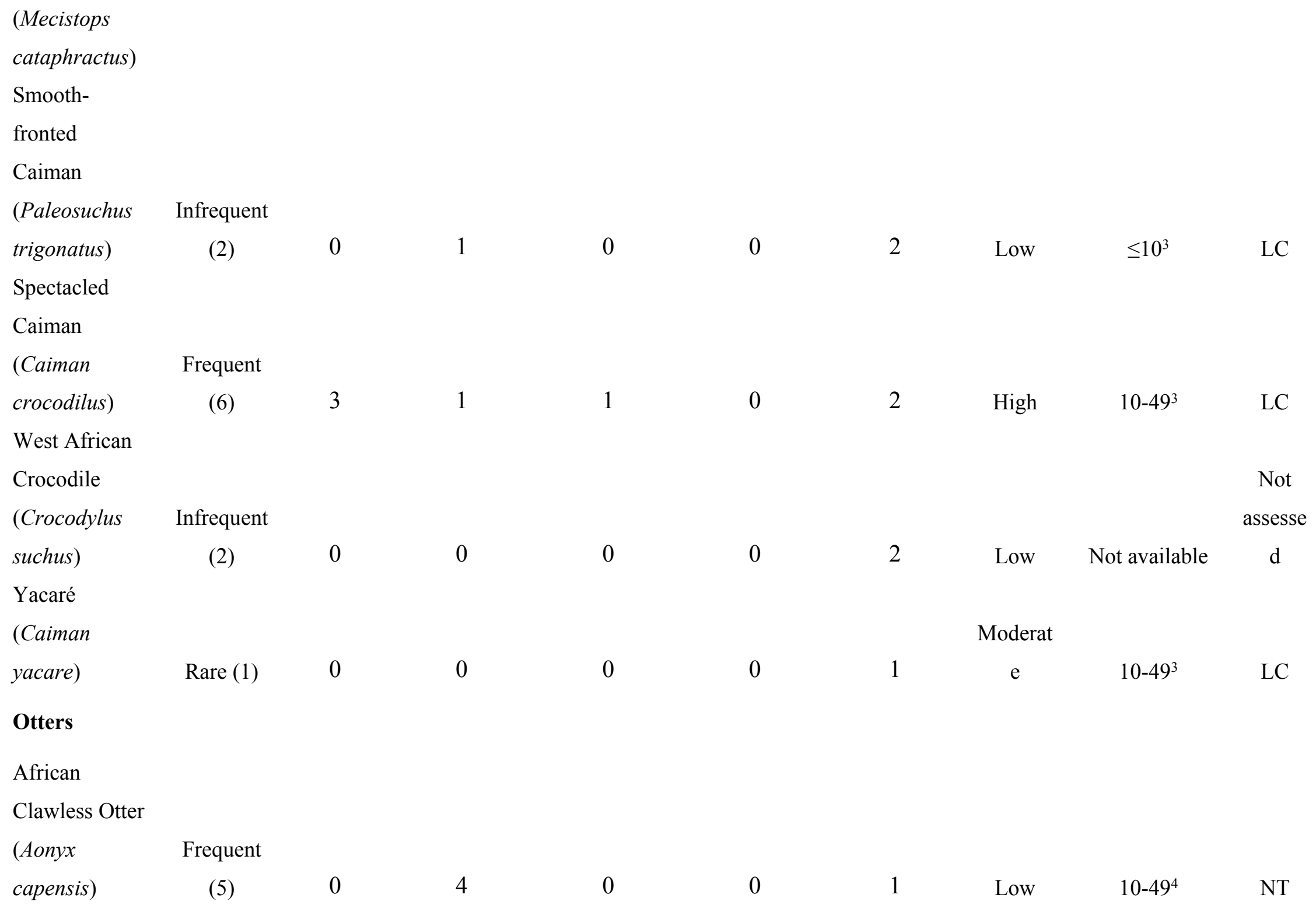


Asian Small-

clawed Otter

(Aonyx Infrequent

cinereus)

(2)

0

2

0

0

Low

$\leq 10^{4}$

VU

Congo

Clawless Otter

(Aonyx Infrequent

congicus)

0

2

0

0

0

Low

$10-49^{4}$

NT

Eurasian Otter

(Lutra lutra)

DD (0)

0

0

0

0

0

DD

$10-49^{4}$

NT

Giant Otter

(Pteronura

Frequent

brasiliensis)

(11)

0

9

0

0

2

Low

$10-49^{4}$

EN

Hairy-nosed

Otter (Lutra

sumatrana)

DD (0)

0

0

0

0

0

DD

$\leq 10^{4}$

EN

Neotropical

River Otter

(Lontra

longicaudis)

Frequent

North

American

River Otter

(Lontra

Rare (1)

(7)

0

6

0

0

1

Low

$\leq 10^{4}$

NT

Moderat

0

0

e

$10-49^{4}$

LC 
canadensis)

Smooth-coated

Otter

(Lutrogale

perspicillata)

Frequent

Spotted-

(6)

5

0

0

Low

$\leq 10^{4}$

VU

necked Otter

(Hydrictis

Frequent

maculicollis)

(6)

0

0

Low

$\leq 10^{4}$

NT

\section{Cetaceans}

Amazon River

Dolphin (Inia

Frequent

geoffrensis)

(14)

0

4

9

0

Low

$\geq 50^{5}$

EN

Baiji (Lipotes

Infrequent

vexillifer)

(4)

0

0

4

0

0

Low

$\geq 50^{5}$

CR

Irrawaddy

Dolphin

(Orcaella

Infrequent

brevirostris)

0

0

3

0

0

Low

$\geq 50^{5}$

EN

South Asian

River Dophin

(Platanista

Frequent

gangetica)

(14)

0

1

12

0

Low

$\geq 50^{5}$

EN 


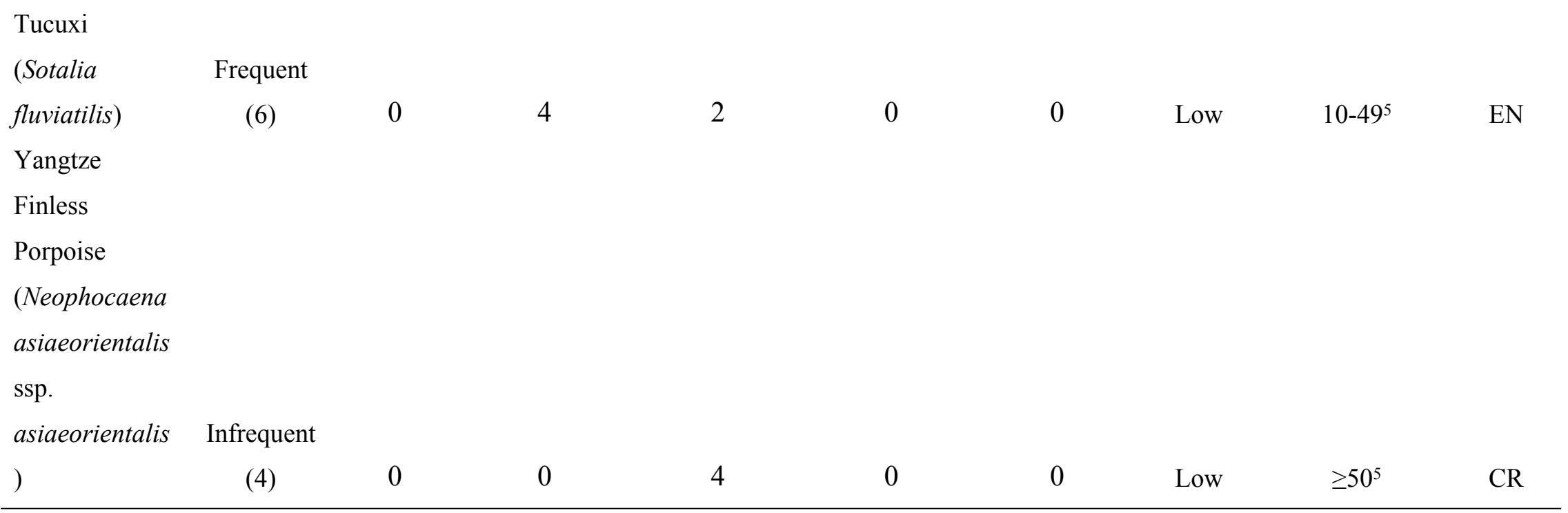

4

$5{ }^{1}$ See Table 1 for description of categories; DD = Data Deficient.

$6 \quad{ }^{2}$ A study was not mutually exclusive to any single type of conflict.

$7 \quad{ }^{3}$ Lakin et al. (2020)

$8 \quad{ }^{4}$ Hunter (2011)

$9 \quad{ }^{5}$ Macdonald (2009)

$10{ }^{6}$ Conservation status according to the Red List categories of the International Union for Conservation of Nature (IUCN): LC= Least

11 Concern, NT= Near Threatened, VU= Vulnerable, EN= Endangered, CR= Critically Endangered. 


\section{Table 3 (on next page)}

Number of species per IUCN Red List status $(n=33)$ and body mass category $(n=34)$ in each conflict severity category. 
1 Table 3. Number of species per IUCN Red List status $(n=33)$ and body mass category $(n=34)$

2 in each conflict severity category.

\begin{tabular}{ccccc}
\hline & \multicolumn{5}{c}{ Conflict Severity Category $^{1}$} \\
& Low & Moderate & High & Severe \\
\hline IUCN Red List Status ${ }^{2}$ & & & & \\
CR & 4 & 3 & 0 & 0 \\
EN & 5 & 0 & 0 & 0 \\
VU & 3 & 0 & 1 & 2 \\
NT & 4 & 0 & 0 & 0 \\
LC & 1 & 4 & 4 & 2 \\
& & & & \\
Body Mass Category (kg) & & & & \\
$\leq 10$ & 5 & 0 & 0 & 0 \\
$11-49$ & 5 & 6 & 2 & 0 \\
$\geq 50$ & 7 & 1 & 3 & 4 \\
\hline
\end{tabular}

3

$4 \quad{ }^{1}$ See Table 1 for description of categories.

$5{ }^{2}$ Conservation status according to the Red List categories of the International Union for

6 Conservation of Nature (IUCN): LC $=$ Least Concern, NT= Near Threatened, VU= Vulnerable,

$7 \mathrm{EN}=$ Endangered, $\mathrm{CR}=$ Critically Endangered.

8

9 